\title{
Cerebral Calcification
}

National Cancer Institute

\section{Source}

National Cancer Institute. Cerebral Calcification. NCI Thesaurus. Code C40461.

Abnormal deposits of calcium in the cerebral tissue. 